WellBeing International

WBI Studies Repository

6-2009

\title{
Exponential Growth, Animal Welfare, Environmental and Food Safety Impact: The Case of China's Livestock Production
}

Peter J. Li

University of Houston

Follow this and additional works at: https://www.wellbeingintlstudiesrepository.org/acwp_faafp

Part of the Agribusiness Commons, Animal Studies Commons, and the Other International and Area Studies Commons

\section{Recommended Citation}

Li, P. J. (2009). Exponential growth, animal welfare, environmental and food safety impact: The case of China's livestock production. Journal of agricultural and environmental ethics, 22(3), 217-240.

This material is brought to you for free and open access by WellBeing International. It has been accepted for inclusion by an authorized administrator of the WBI Studies Repository. For more information, please contact wbisr-info@wellbeingintl.org.

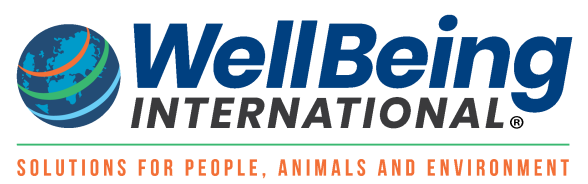




\section{JAGE-A459}

Exponential Growth, Animal Welfare, Environmental and Food Safety Impact: The Case of China's Livestock Production

( published in Journal of Agricultural and Environmental Ethics, 2009, Vol, 22, pp. 217-240)

Peter J. Li, Ph.D.

Associate Professor of East Asian Politics

Social Sciences Department

University of Houston-Downtown

One Main Street, Suite N1009F

713-221-2741

lip@uhd.edu 


\begin{abstract}
Developmental states are criticized for rapid "industrialization without enlightenment." In the last 30 years, China's breathtaking growth has been achieved at a high environmental and food safety cost. This article, utilizing a recent survey of China's livestock industry, illustrates the initiating role of China's developmental state in the exponential expansion of the country's livestock production. The enthusiastic response of the livestock industry to the many state policy incentives has made China the world's biggest animal farming nation. Shortage of meat and dairy supply is history. Yet, the Chinese government is facing new challenges of no less a threat to political stability. Production intensification has created a welfare crisis impacting the world's biggest number of farm animals. The resulting food safety incidents are affecting consumer confidence and health. Untreated waste contributes to the nation's environmental degradation. Developmental states may have a proud record of growth in the initial stage of industrialization. Their prospects for sustained development have long been questioned. China has come to an important juncture to march towards a sustained development.
\end{abstract}

Key words: China's livestock production, developmental state, environmental degradation, animal welfare, food safety, public health

\title{
Introduction
}

In September 2008, a shocking food poisoning incident electrified the Chinese public. A brand name Chinese baby formula was blamed for the death of four infants and sickening 54,000 across the country. ${ }^{1}$ What made the public more agitated was the revelation that the local government concerned had tried to cover up the incident and to prevent the local media from reporting it. Sanlu Dairy Corporation, the producer of the tainted formula, had by the outbreak of

\footnotetext{
${ }^{1}$ See Zhou Tingyu et al (2008).
} 
the incident been a model business and one of the top dairy producers in China holding about $18 \%$ of the national dairy market share. Sanlu was a major revenue contributor to Shijiazhuang, the capital city of Hebei province. The fact that this model business with hundreds of awards ranging from an exemplary corporate member to a scientific innovator is now implicated in the nation's worst product safety case is thought-provoking. To the Chinese consumers, if this socalled model business could churn out poisonous products, are there socially responsible corporations in China?

When reports on the incident finally emerged in a nearby province, the Chinese government responded quickly and pointedly. The chief executive of Sanlu, a deputy to the National People's Congress, was detained. Also arrested were 27 dairy farmers and milk collection station operators. The head of the national product quality bureau was forced to resign. Despite these arrests, resignation, and heightened quality inspection of the dairy products on the markets, public anger has been fermenting. Amid increasing public calls for holding government accountable for the out-of-control food safety problem, the Chinese government has been trying to channel public anger at the "small number of heartless entrepreneurs" and dairy farmers. Official media has intensified reports of the government as the guardian of public safety. Wen Jiabao, the prime minister, announced to the nation that he can be trusted to be at the forefront whenever a crisis takes place. ${ }^{2}$ Food safety is a new challenge to political stability. ${ }^{3}$

China is a reforming Leninist Party-state. Despite market liberalization since the early days of the reform, China has retained much state control over the nation's economic life.

The blame on the individual dairy farmers and the milk collection center operators for the tainted milk has been questioned. This paper uses a field study of China's animal farming industry and its growth in response to government policy incentives to illustrate the part of China's reforming state in the nation's economic accomplishments and problems. We argue that China's worsening environmental, food safety, and public health problems have a lot to do with the government's reform politics. The Chinese government is as much a part of the food safety problem as of a solution.

Structurally, this paper starts with an introduction of the developmental state. The review focuses on its role in economic growth and its limitations in social progress. It establishes the

\footnotetext{
${ }^{2}$ See Zhang, Suo. (2008).

${ }^{3}$ See Zhao, Shengyu (2003).
} 
Chinese reforming state as the explanatory variable of China's livestock industry transformation. In the next section, we shall introduce the results of our study of China's livestock industry. Emphasis is placed on the rate of the increase, structural change, and welfare conditions of the farms investigated. Following the survey results, we shall trace the industry's expansion to the several landmark policy incentives. These were policies that jumpstarted farm animal production, removed obstacles to industry expansion, and encouraged industry modernization. Finally, we shall examine the new environmental and public health problems that have accompanied the growth of the nation's livestock production. We argue that, like all other developmental states, the Chinese government's obsession with growth explains the many growth ailments impacting environment and public health.

\section{Developmental State and Obsession with Growth}

Developmental states are a unique group of nations conceptually positioned between the open market economies and centrally-planned socialist states. In his study of "China as a developmental state," Andrzej Bolesta provides a good summary of the features of such states. First, it is "a state in which the authorities' objectives are to achieve fast socio-economic development." ${ }^{4}$ Motivations behind the authorities' focus on development can be economic backwardness, ${ }^{5}$ government legitimacy crisis and security threats. Backwardness forced Bismarck's Prussia and Japan in the mid- $19^{\text {th }}$ century to seek ways to catch up with the industrialized nations so that they would not be left behind further. The Republic of China on Taiwan under Chiang Kai-shek faced the twin threats of internal revolt and invasion from the Communist mainland in the early 1950s. Motivation for growth was understandably enormous for Chiang.

Second, a developmental state is authoritarian. It maintains a competent bureaucracy insulated from the society. Through the state bureaucrats, the developmental state "dictates not only the norms and rules of the social, political, and economic existence, but also the directions of development." ${ }^{6}$ It is therefore an interventionist state. Apart from the authoritarian institutional setting and developmentalist ideology, developmental states take proactive approach

\footnotetext{
${ }^{4}$ See Bolesta, Andrzej, (2007, p.109).

${ }^{5}$ See Gerschenkron, Alexander (1962) Economic Backwardness in Historical Perspective.

${ }^{6}$ Bolesta, Andrzej. (2007, p.109).
} 
to build a congenial policy environment for achieving the objective of rapid growth. Yet, unlike the more predatory central planning socialist states, the developmental states act more as a regulator and facilitator or in the characterization of Peter Evans as a "custodian," "demiurge," "midwife" and "husbandry."7 In these roles, developmental states regulate, assist, and motivate the private sector, particularly the target industries to seize growth opportunities and face challenges. Because of the effectiveness of government policies, one perspective sees government policies as a comparative advantage in state's efforts to promote growth or to shield the national economy from adverse outside impacts. ${ }^{8}$

Third, despite its interventionist nature, a developmental state oversees a capitalist economy. Private production and other non-state sectors are important contributors to growth. In East Asia, private enterprises are known to respond quickly to signals of state policy change besides opportunities created by a protected domestic markets. Unlike in a socialist centrally-planned economy where the means of production belong to the state, a developmental state protects private ownership. Government policies serve to define the perimeters of permissible corporate behaviors like in liberal open economies, direct resources to state-defined priority sectors or productions, and assist industry expansion and modernization. Admittedly, the state bureaucracy must keep abreast of the world latest industrial progress to be able to guide growth in a desired direction.

Fourth, in developmental states, civil society develops slowly. Building an open society and democratic institutions is not a priority, still less in the initial stage of development. In Bruce Cumings's view, the East Asian developmental states should be construed as "bureaucraticauthoritarian industrializing regimes." Laborers, students and intellectuals used to face draconian laws against autonomous societal activities. Voices against state-led capitalist development were often and sometimes brutally silenced. ${ }^{9}$ "East Asia has meant industrialization without Enlightenment, ..."10 Underdeveloped civil society has shielded the businesses from environmentalists and from consumers violated by problem products. Often, national security and domestic stability are used as a justification for limiting civil liberties and

\footnotetext{
${ }^{7}$ See Evans, Peter. (1995). Embedded Autonomy. p.14.

${ }^{8}$ See for example,Krueger, Anne O. (1980); Loriaux, Michael (1991, p.34-38); Dalia Marin, Dalia (1995); and Bradford, Jr., Colin I. (publication year unknown).

${ }^{9}$ See Cumings, Bruce (1999). 'Webs with No Spiders, Spiders with No Webs: The Genealogy of the Developmental State.' In Meredith Woo-Cumings ed., The Developmental State p. 70.

${ }^{10}$ Woo-Cumings. Meredith. (1999, p. 90).
} 
restricting societal forces that are considered to have parochial interests and myopic concerns in the way of the state's growth-oriented development strategy.

Finally, developmental states are attracted to foreign advanced technology and production models. States that are late to industrialize "ardently desire modern technology: it is their passport to modernity, their membership card in the twentieth century." ${ }^{11}$ Therefore, developmental states pursue an open door policy towards the industrialized West. While efficiency and productivity can be achieved through foreign learning and adoption of foreign advanced technology, modern Western attitude towards nature is also accepted. In his book Development Ethics: A Guide to Theory and Practice, Denis Goulet has the following comments on the adverse impact of Western technology transfer:

Nothing is sacred to them (the technocrats): the earth, and nature itself, are there to be mastered - and altered in the process. ...While Western technology promotes certain values of rationality, efficiency, and problem-solving, it also threatens or destroys other key values when "transferred" to Third World countries. ${ }^{12}$

The reforming Chinese government is a post-socialist developmental state. ${ }^{13}$ Economic growth or, in the words of Deng Xiaoping, "developing productivity" was and is still the primary objective of China's reforming government. As a developmental state, how has China's reforming state pushed for production expansion of the nation's livestock industry? How successful have the government's efforts been? In the next two sections, we shall first introduce China's animal farming industry and its changes in the last 30 years to gauge the effectiveness of the state role. Following this introduction, we shall review the landmark policies that have been adopted with the aim of facilitating livestock industry expansion.

\section{China's Livestock Production and a 30-year Growth}

\footnotetext{
${ }^{11}$ See Goulet, Denis. (1995, p.105-106).

${ }^{12}$ Goulet, Denis. (1995, p.108)

${ }^{13}$ See Deans, Phil (2004) 'The People's Republic of China: The Post-Socialist Development State' in Linda Low (2004, p.133-146).
} 
Increasing agricultural productivity was the top priority when the reforming Communist Party leadership initiated the reform program in 1978. Since then, farm animal production, an important part of the rural sector, has grown rapidly. Chinese peasants are known to be most sensitive and responsive to changes of the government policies. The growth trajectory of the nation's livestock production reflects the interaction between state policies and industry responses.

Growth, Diversification, and Product Structural Change

Meat output is indicative of the growth of China's livestock production. In 2006, China produced a total of 78 million tons of meat, about $600 \%$ increase over that of 1978 . In terms of annual average growth, China maintained an impressive $7.6 \%$ increase rate in the last 26 years. In contrast, worldwide meat production in the corresponding period grew at $3 \%$ per year only. In 1978, China's meat production accounted for $7.8 \%$ of the world total. Its population in that year represented $25 \%$ of the world's total. In 2006, China's share in world meat output rose to $29 \%$. This accomplishment was at a level commensurate to its share of the world's population.

Table 1: A Comparison of Meat Production in China and in the World:1978 - 2004.

\begin{tabular}{|l|l|l|l|l|}
\hline Year & $\begin{array}{l}\text { China Total } \\
\text { million tons) }\end{array}$ & $\begin{array}{l}\text { Growth over } \\
\text { Previous Year } \\
\text { (in \%) }\end{array}$ & $\begin{array}{l}\text { World Total } \\
\text { million tons) }\end{array}$ & $\begin{array}{l}\text { As \% of the } \\
\text { Total }\end{array}$ \\
\hline 1978 & 11.10 & & 127.44 & 8.7 \\
\hline 1979 & 13.35 & 20.27 & 132.69 & 10.0 \\
\hline 1980 & 14.79 & 10.78 & 136.68 & 10.8 \\
\hline 1982 & 16.44 & 6.47 & 140.58 & 11.7 \\
\hline 1984 & 18.58 & 8.78 & 149.34 & 12.4 \\
\hline 1985 & 20.94 & 12.75 & 154.42 & 13.6 \\
\hline 1987 & 24.06 & 5.11 & 164.93 & 14.6 \\
\hline 1988 & 26.70 & 10.97 & 171.21 & 15.6 \\
\hline 1992 & 36.40 & 9.08 & 189.05 & 19.3 \\
\hline 1993 & 40.54 & 11.37 & 194.05 & 21.0 \\
\hline
\end{tabular}




\begin{tabular}{|l|l|l|l|l|}
\hline Year & $\begin{array}{l}\text { China Total } \\
\text { million tons) }\end{array}$ & $\begin{array}{l}\text { Growth over } \\
\text { Previous Year } \\
\text { (in \%) }\end{array}$ & $\begin{array}{l}\text { World Total } \\
\text { million tons) }\end{array}$ & $\begin{array}{l}\text { As \% of the } \\
\text { Total }\end{array}$ \\
\hline 1995 & 48.24 & 7.87 & 206.72 & 23.3 \\
\hline 1997 & 54.72 & 13.9 & 216.08 & 25.3 \\
\hline 1998 & 59.12 & 8.04 & 224.35 & 26.3 \\
\hline 2000 & 63.19 & 5.26 & 235.06 & 26.8 \\
\hline 2003 & 71.18 & 4.98 & 253.53 & 28.1 \\
\hline 2004 & 74.43 & 4.56 & 259.37 & 28.7 \\
\hline
\end{tabular}

Source: FAOSTAT 2005

Several points should be made about China's livestock production figures in table 1. First, despite the impressive average growth rate, we see vicissitudes in growth in the years included in the table. Significant growth can be attributed to government actions in the year immediately preceding the increase. The $20.27 \%$ growth in 1979 , for example, was a positive response to the new Party policy de-criminalizing non-grain production. Yet, in the next four years, average growth rate of meat production was maintained at $6.86 \%$. In 1983, it even dropped to $3.89 \%$ over the previous year. According to a Chinese provincial agriculture bureau official, enthusiasm for livestock farming cooled down. Peasants who intended to expand production were hesitant to proceed while those who intended to enter the production were watching to see if they should throw their limited funds into the production. One reason underlying the hesitation was the fear that government policies could change. ${ }^{14}$

The Chinese government saw the peasant's wait-and-see attitude. It responded with new policies to address peasants' fear. The 1984 policies allowing the use of market price for farm animal sales and state decision to reduce the number of farm products under state compulsory procurement plan served as a further assurance to the peasants. The growth rates for 1984 and 1985 as a result went up to $8.78 \%$ and $12.75 \%$ respectively. Similarly, big output increase in

\footnotetext{
${ }^{14}$ Interview with a provincial agriculture bureau official, June 14, 2005.
} 
1988 and 1993 happened as a result of the $13^{\text {th }}$ Party Congress of 1987 and of Deng Xiaoping's famous 1992 speeches on the need to continue economic reform and opening to the outside. ${ }^{15}$

Second, the steady growth was achieved by both the modern farms and the millions of peasant backyard farms. For example, in 1989, 93\% of the peasant households in a southern Jiangxi township raised on average 3 pigs, 21 ducks, 17 chicken (laying hens and roosters combined), and 7 geese a year. Many peasant households had also been engaged in wildlife farming such as frog, snake, civet cats, turtles and others to supply the markets in nearby Guangdong, China's wildlife eating capital. ${ }^{16}$ Even though specialized livestock farming has developed rapidly in the rural area, China's animal farming by the end of 2003 had remained dominated by scattered individual peasant household-run farms. In pig, dairy cow, beef cattle, sheep/goat, layer and broiler farming, peasant household-based farms accounted for $93.77 \%$ of the farm total producing $44.14 \%$ of the livestock slaughtered. And, $94.46 \%$ of China's pig farms were small scale operations owned by individual peasant families. ${ }^{17}$

In 2003, China had 101,963,901 such household-owned pig farming operations raising 1 to 9 pigs. They produced $52.86 \%$ of the pigs slaughtered in the year. Peasant farms represented $85.17 \%, 97.25 \%, 95.71 \%$ and $96.31 \%$ of the total number of the dairy cow, beef cattle, laying hen and broiler farms. ${ }^{18}$ The fact that some one hundred million peasant households are involved in animal farming should speak volumes about the peasant response to the Party's call to diversify agricultural production.

Third, what the table does not show is that China's livestock production has undergone a product structural change in response to proactive state initiatives and policy endorsements. Today, pig farming continues to dominate China's livestock industry. Yet, that domination is eroding. In 1972 of the pre-reform era, for example, China's total meat output was 9,614,701 tons. Pork accounted for $81.9 \%$ while poultry, beef, and mutton made up $11.4 \%, 2.39 \%$ and $1.40 \%$ respectively. ${ }^{19}$ Since 1978 , the weight of pig farming has been steadily going down. A comparison of the farm animal distribution in total livestock farming in 1978 and 2004 highlights the changes in product structure.

\footnotetext{
${ }^{15}$ For Deng Xiaoping's speech on the need to continue economic reform and opening to the outside world, see Chinese Communist Party Central Document Research Institute (2004, p.1341-1345).

${ }^{16}$ Interview of southern Kiangsi officials of the prefecture animal husbandry bureau, June 17, 2005.

${ }^{17}$ See China Animal Husbandry Industry Yearbook Compilation Committee. (2005, p. 225-237).

${ }^{18}$ China Animal Husbandry Industry Yearbook Compilation Committee. (2005, p. 225-226).

${ }^{19}$ UN FAO data.
} 
Chart 1: Comparison of Meat Production by Livestock (1978 v 2004)

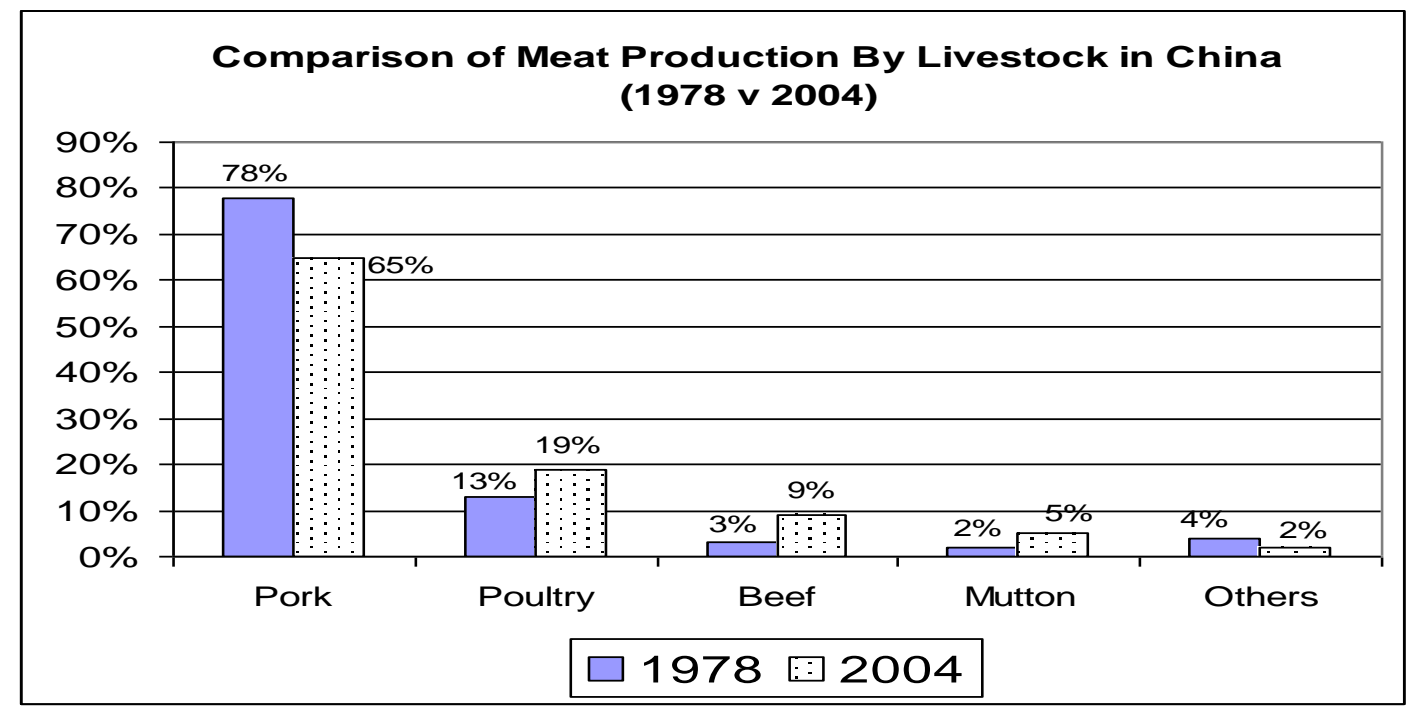

Data source: FAOSTAT, 2005.

In 2004, pork production topped the production list with its 48 million tons of output (out of a total of 74 million tons) followed by chicken (9.8 million), beef (6.8 million) and sheep/goat meat (3.9 million tons). Output of pork, poultry, beef, and mutton represented $65 \%, 19 \%, 9 \%$, and $5 \%$ of the total. Beef and mutton production has grown faster in recent years. For example, beef and sheep/goat meat output increased by $7.88 \%$ and $10.58 \%$ over the previous year. ${ }^{20}$

Fourth, dairy production has expanded exponentially. China's milk production since 1978 has grown at $9 \%$ on average. In 1978, it produced 2.8 million tons of milk, only $3 \mathrm{~kg}$ per person. In 2004, milk production reached 22.9 million tons, an increase of 7.17 times over that in 1978 . Despite China's population of 1.3 billion in 2004, per capita milk production went up to $17.6 \mathrm{~kg}$. In the first few years of the new century, milk production accelerated. It grew by $10 \%, 17 \%$, $19 \%$, and $26 \%$ in $2000,2001,2002$, and 2003 . This pace of growth has slowed down a little since 2003 as a result of industry consolidation and fierce competition for market shares. In 1978, China's milk production accounted for an insignificant $0.61 \%$ of the world total. That figure rose to $3.7 \%$ in 2004. To the Chinese agricultural bureaucrats in Beijing, China has great room to catch up with the advanced countries in milk production.

\footnotetext{
${ }^{20}$ UN FAO data.
} 
By 2005, China had been the world's biggest egg producer for 20 years. In 1985, it produced 5.5 million tons of eggs, $17.05 \%$ of the world total of 32.5 million. Since then, China's production and its share in the world total have ascended to a new level. In 1990, it produced 8.1 million tons, making up $21.79 \%$ of the world gross egg output. In 2000, its share went up further to $40.9 \%$. Four years later, China produced $45.04 \%$ of the world's eggs. ${ }^{21}$

Looking back, 1978 represented a milestone in China's egg production. Its growth rate was most dramatic between 1987 and 2002. Per capita egg production in 2002 reached $18.71 \mathrm{~kg}, 8.28$ times of that in 1962. In 1991, China's per capita egg production exceeded world per capita average. Four years later, China overtook the industrialized nations in per capita egg production. Despite the fact that egg production has stabilized since 2002, the peak year of growth, the growth rate is still maintained at a level significantly higher than that of the world and of the industrialized nations (See chart 2). ${ }^{22}$

Chart 2: Per Capita Egg Production: China, Industrialized Nations, and World

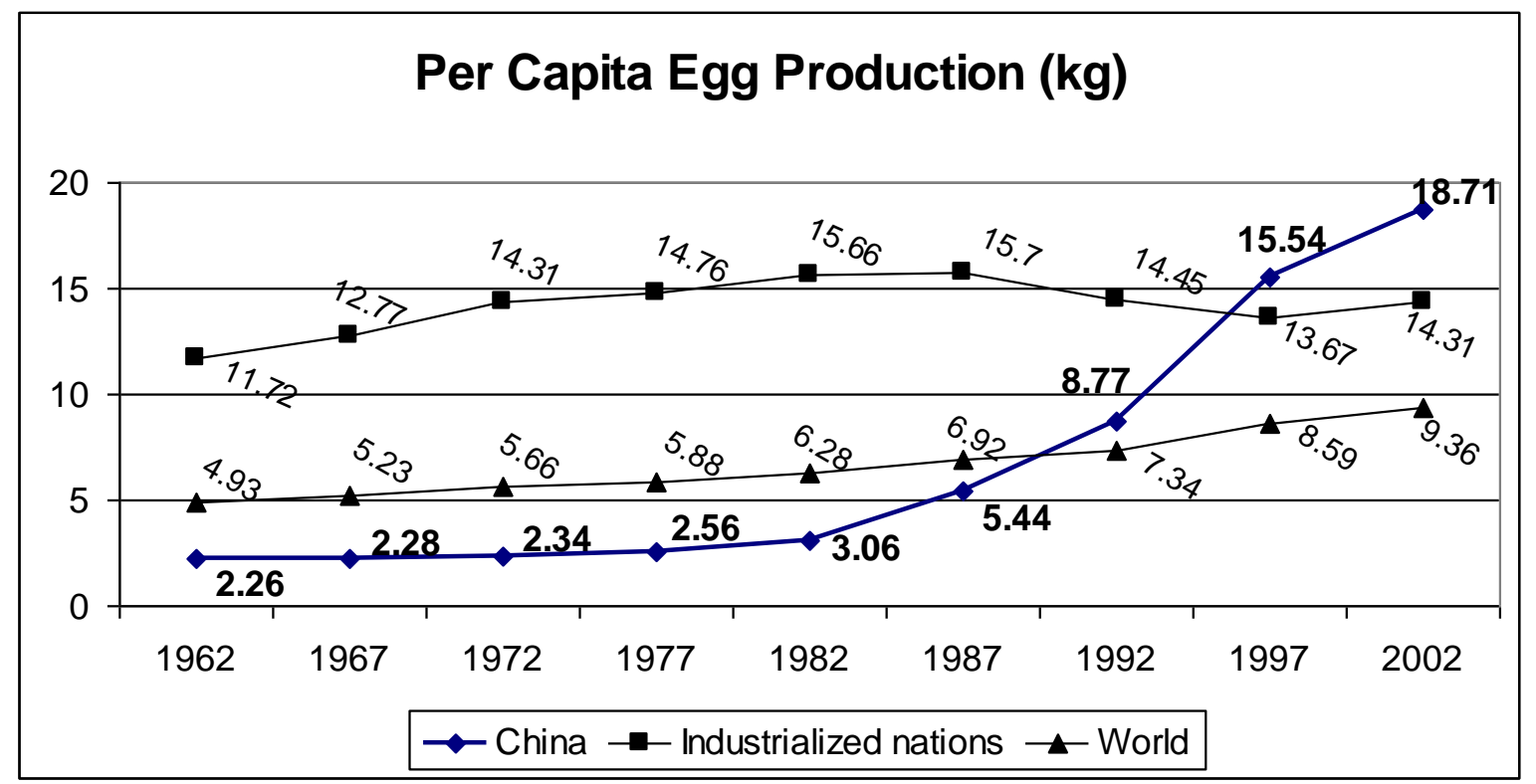

Data source: China Animal Husbandry Industry Association

\footnotetext{
${ }^{21}$ Lu, Xianru (2004).

${ }^{22}$ CAAA website (2004).
} 


\section{Animal Farming in Rural Economy}

Promoting livestock production with the aim of increasing its share in the rural output has long been a policy objective of China's reforming state. The share of livestock farming in the grainproducing regions grew most rapidly. Overall, China's animal husbandry industry has increased from $17 \%$ of the gross agricultural product in 1978 to $34 \%$ in 2004 . Provinces with the highest percentage of animal farming in gross agricultural production included three traditional and seven non-traditional animal farming provinces. Even though animal farming in Qinghai, Tibet, and Inner Mongolia accounted for $53 \%, 46 \%$, and $40 \%$ of their respective gross agricultural output, these big percentages were maintained because they were agriculturally less developed. Chart 3 illustrates the "inroad" of livestock production into the grain-producing provinces. ${ }^{23}$ And the "inroad" took place after the authorities' repeated policy statements on the need to utilize grain byproducts for livestock production.

\footnotetext{
${ }^{23}$ Grain production has been stable in the top producing provinces since the mid-1990s. The top 8 grain producers in China are Shandong, Henan, Sichuan, Jiangsu, Heilongjiang, Hebei, Hunan, and Jilin. See "Yield of Major Farm Crops by Region" in Department of Comprehensive Statistics of National Bureau of Statistics. (2000, p.121).
} 
Chart 3: Animal Farming as a Percentage of Total Agricultural Output (2004)

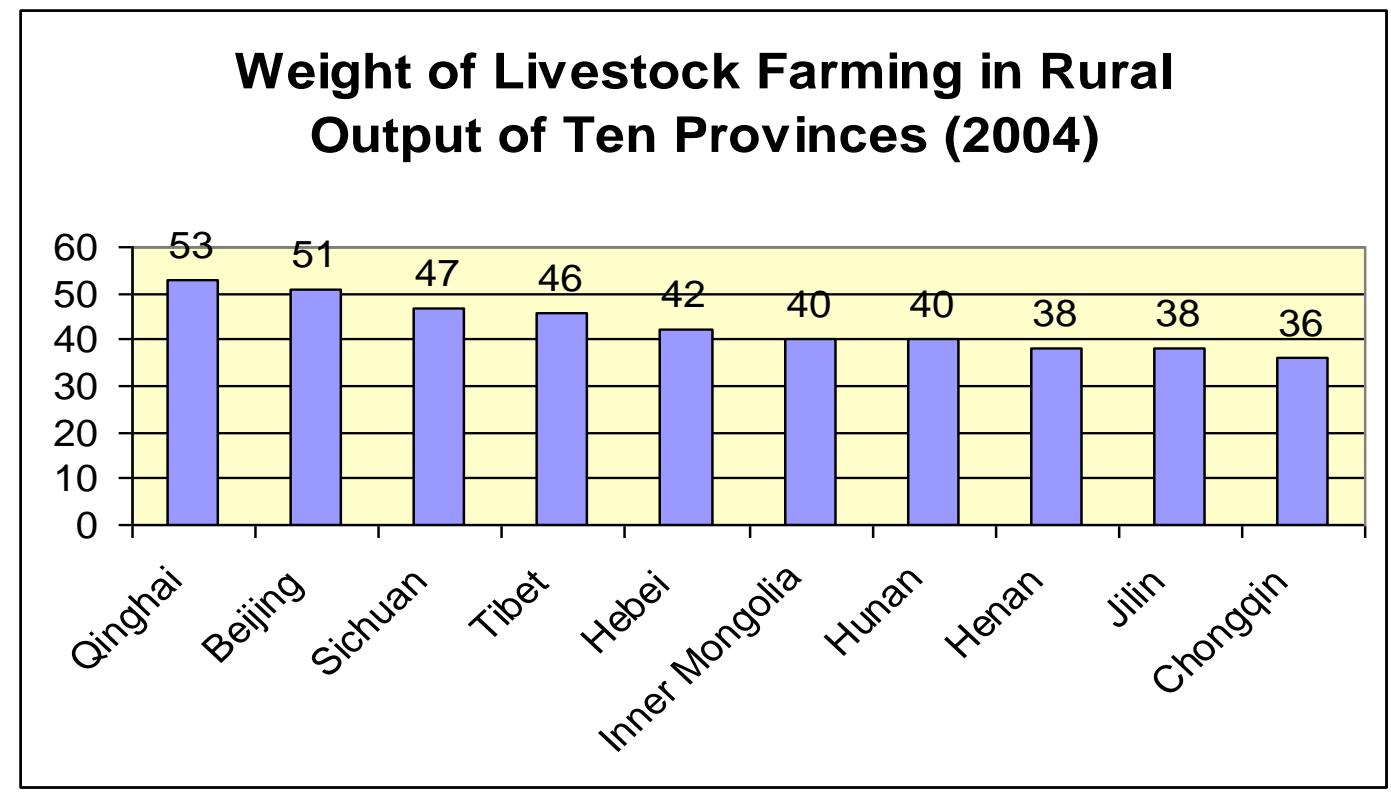

Data source: China Animal Husbandry Industry Association

Penetration of Intensive Farming Model

Like other countries late to industrialize, China is enthusiastic about adopting advanced foreign technology and production models. Open policy is part of China's reform strategy. This policy encourages Chinese businesses to look to the industrialized nations, in the case of livestock production, for fine breeds, joint ventures, production models, and productivity enhancing farming tools. A 2005-2006 field study of 35 Chinese intensive farms we conducted confirmed the Chinese attraction to the Western model of livestock production. ${ }^{24}$

These 35 farms were not chosen randomly. Yet, we made it clear to farm visit organizers in the cities of our visit that we wanted to visit farms that were modeled on Western factory farms. Peasant household farms were excluded. Since the research objective was to find out the penetration of Western livestock farming practices in China, farms recommended by local authorities did not constitute a self-selection problem. To Chinese officials, adoption of the Western farming model was a proud sign of progress. They generally thought that farm animals lived a much better life on the factory farms than on peasant backyard farms. They did not object to show us how open they were to new technology and advanced Western model. Yet, we were

\footnotetext{
${ }^{24}$ See Humane Society International and Compassion in World Farming. (2006).
} 
required to follow the standard quarantine procedures when entering and exiting the farms. The study revealed both a fast-developing sector and one with significant side-effects in environment and public health.

Farm Size, Ownership, and Share of Output

From the very beginning of the reform program, livestock production has been a predominantly private peasant household-based operation. The Chinese reforming state has had no problem with the private nature of the production. In fact, it was China's developmental state that legalized peasants' private production. To the state agricultural bureaucrats, scattered small-scale peasant household farms were, however, a hindrance to the industry's expansion and modernization. As of the end of 2003, peasant household farms had maintained their dominance in the total number of livestock farms. For example, $94.46 \%$ of China's pig farms, as Chart 4 shows, were small scale operations owned by individual peasant families. In 2003, China had $101,963,901$ such household-owned pig farming units raising 1 to 9 pigs. They produced 52.86\% of the pigs slaughtered in the year.

Chart 4: Peasant Household-based Farms and Share in Output (2003)

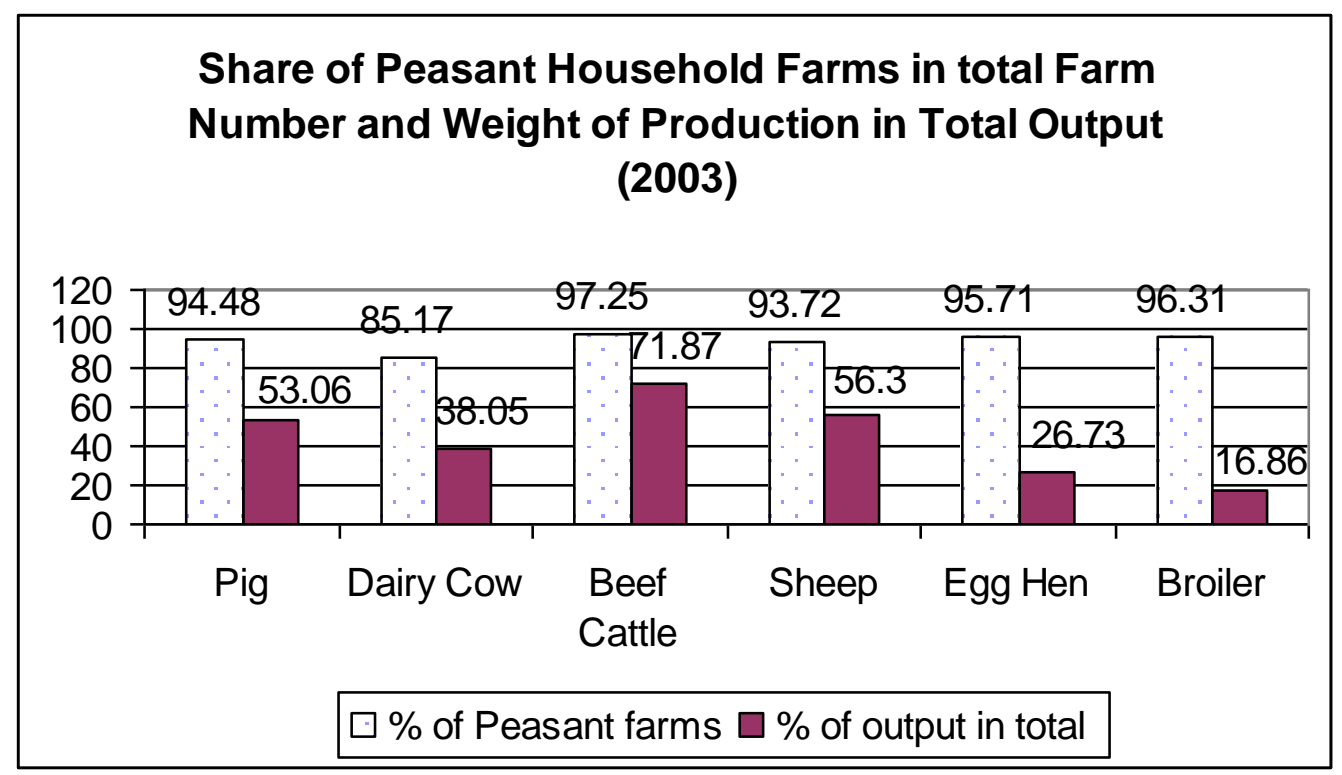

Data source: China Animal Husbandry Industry Yearbook: 2004. 
Peasant household-based operations in dairy cow, beef cattle, laying hen, and broiler farming accounted for $85.17 \%, 97.25 \%, 95.71 \%$ and $96.31 \%$ of the total number of the respective farms. ${ }^{25}$ These backyard farms are small in scale hiring few or no outside helpers. Because of small scale operation, these peasant families only selectively adopt modern farming techniques. Some of the modern practices adopted include use of commercial feed, drugs for disease control and growth promotion, and barren housing. Peasant household-based operations are perceived by the government as a backward mode of production for its limited growth potentials and epidemic control problems.

In 2003, intensive farms producing 50 pigs or more only represented $4.46 \%$ of the total number of pig farms. Dairy cow farming was similar. Farms raising more than 21 cows only made up $2.18 \%$ of the total number of the dairy farms. And, $85.17 \%$ of the dairy farms were small-scale household operations with on average six dairy cows. Medium and large egg farms are even smaller in number. Farms holding more than 2,000 hens (up to 500,000 and more) only accounted for $0.22 \%$ of the farm total. Similarly, in beef cattle farming, medium and large farms (farms that raise between 51 and 1000 and more cattle) only represented $0.33 \%$ of the total. In farm numbers, intensive farms are the absolute minority.

Yet, intensive farms had a disproportionately big share in output and stock numbers. Even though individual peasant household operations accounted for $93.77 \%$ of the farm total, the $6.23 \%$ intensive farms produced $55.86 \%$ of the farm animal products in 2003 . Specifically, $96.31 \%$ of China's broiler output was owned by peasant households. Yet, the $3.69 \%$ of the intensive boiler farms produced $81.14 \%$ of the total for slaughter. Egg farms come next as the most intensive operation. Egg farms of scale $(0.22 \%$ of the farms) held $25.86 \%$ of the laying hens. The $4.46 \%$ intensive pig farms produced in $200346.94 \%$ of China's pigs slaughtered in the year. And, $0.33 \%$ of the cattle farms produced $12.0 \%$ of the beef cattle. ${ }^{26}$ Greater production capacity of these farms was made possible by a wholesale adoption of Western modern farming techniques.

Popularity of Intensive Farming Practices

${ }^{25}$ See China Animal Husbandry Industry Yearbook: 2004 ( 2005, p.225-226).
${ }^{26}$ See China Animal Husbandry Industry Yearbook: 2004 (2005, p. 227-235). 
Despite the small number of intensive farms, the popularity of Western farming model and practices in China is obvious. The 35 intensive farms we studied were located in three types of provinces, i.e., developed coastal provinces (Liaoning and Beijing), major livestock producer provinces (Sichuan and Inner Mongolia), and inland grain-producing provinces (Jiangxi and Anhui). We had expected greater penetration of factory farming practices in the first two groups of provinces due to their greater openness to the outside world and their big share of livestock production in rural economy. The findings told a different story. Western farming practices have even penetrated Jiangxi and Anhui, two of the most underdeveloped and inaccessible inland provinces. The following four Western practices are singled out here to show their popularity with the Chinese livestock sector.

Gestatation/Farrowing Crates. Gestatation and farrowing crates are the most popular farming tool of Western invention. We noticed them in all 9 breeding farms. Two of these farms were in inland Jiangxi and Anhui. Their wide use across the country is therefore no exaggeration. Sow crates are popular because they ensure success of pregnancy and prevent breeding sows from crashing the piglets. Productivity and efficiency are the attractions. No farm workers and owners appeared to know that use of furrowing crates is to be phased out in European Union nations. ${ }^{27}$ According to the manager of a Liaoning breeding farm, his sows were generally confined up to 150 days in standard crates. ${ }^{28}$ All the interviewees of the breeding farms referred to such modern farming practice glowingly.

Battery Cages. Battery cages are another Western farming practice widely used on layer farms in both the coastal and inland provinces. The smallest of the eight layer farms we visited had, at the time of our visit, 4,000 laying hens while the biggest kept 200,000 birds. Each bird was confined in individual cage of about 450 square cubic centimeters. To the Chinese livestock industry, battery cages were "scientific" productivity enhancing tool.

In China, battery cages is a fit in any environment and in any housing facilities. They are installed under asphalt felt-covered sheds erected in the middle of rented farmland; they are installed in makeshift chicken house converted from the old workshops of bankrupt state-owned factories; and they are installed in extremely dark and poorly ventilated old farmhouses. Stocking

\footnotetext{
${ }^{27}$ Arey, Dale and Phil Brooke. (2006, particularly chapter 6).

${ }^{28}$ Conversation with a farm manager in Northeast China's Liaoning Province, June 20, 2005.
} 
density on the egg farms vary. But, they are generally crowded. Most farms installed two tiers of cages while some have three tiers. The large number of birds in one housing in Jiangxi makes the indoor air suffocating. Because of high stocking density, de-beaking is practiced. Four of the eight egg farms we studied conducted de-beaking, another practice of factory farms. Also revealed was an average $10 \%$ of mortality rate per year on both the egg and broiler farms. Three of the farms disposed of the dead hens in a way that could allow these dead birds to sneak into the food market.

Mutilation and Early Weaning. Mutilation is a standard practice of factory farms. It mostly refers to tail-docking, teeth-cutting, and castration. The objective of tail-docking and teeth cutting is to reduce mortality caused by injuries incurred from fighting while castration is to eliminate boar taint. ${ }^{29}$ Eight out of the nine breeding farms castrated male piglets without using anesthetics or pain-killers. In China, castration is performed to allow faster growth and growth beyond estrus rather than to eliminate the boar taint. Tail docking was done for the same purpose on eight of the nine breeding farms. Tail-docking is usually done on the second or third day after the piglets' birth. Similarly, beak trimming is widely practiced on Chinese intensive farms in all three regions.

Common to most intensive farms is early weaning. Out of the eight pig breeding farms of our investigation, seven farms wean their piglets in the $3^{\text {rd }}$ and $4^{\text {th }}$ week, or 21 to 25 days after birth. Only one farm has a weaning date that is one week longer. Dairy cow weaning is significantly earlier. Five out of the nine farms wean their calves in a matter of two or three days. These calves are separated from their mothers and are individually kept. Four other farms wean their calves in 4 to five weeks. These practices have one objective in mind, i.e., productivity and cost reduction.

Substance and Drug Use. Use of industrial chemicals, human drugs, banned chemical compounds, and anti-biotic in farm animal feed is no secret in China. Pigs, for example, have long been fed Clenbuterol, a synthetic steroid, to increase lean meat. This so-called "muscle creator," "magic potion," or "Armit mitserhem" can help pigs gain up to 100 kilograms in weight in a month. It was also reportedly found in chicken feed for layers to produce more eggs and for

\footnotetext{
${ }^{29}$ Arey, Dale and Phil Brooke. (2006, chapter 7).
} 
broilers to grow faster. Little consideration is given by those who use this substance in feed to its adverse impact on farm animals and humans. Increasing productivity by cutting in half or more of the normal growth time is the primary target. Pigs that have bigger muscles and less fat can sell at a higher price. Resorting to "science" to increase productivity is not a traditional farming practice. Factory farms in the West have long been known to rely on a wide variety of growth promoting substances.

Anti-biotic is another form of growth promoting substance that has been abused on Chinese intensive farms. Workers at all 35 farms said that they used anti-biotic drugs "when necessary." To the intensive farms, "when necessary" covers a wide range of occasions such as when there is the need for cutting growth time, preventing or controlling disease, and getting the animals ready for transport to the slaughterhouses. You would think that "when necessary" happens very often especially on most of the chicken farms and two pigs farms we visited where sanitation and space allowance were a big problem. Stocking size in confined space has been positively linked to livestock aggression, which creates potential injuries and disease outbreak. ${ }^{30}$ To preclude the outbreak of a devastating epidemic, farm owners rely heavily on drugs. Drug residual level in meat and dairy products often exceeds the minimum level allowed by relevant state regulations. ${ }^{31}$

High drug residue problem was confirmed by the interview we conducted of a broiler slaughterhouse owner. "We have a drug testing lab. But, we do not perform tests on the broilers brought to us by our clients who purchase the young birds from our hatcheries," he answered. He continued, "if we do the tests, all the chickens would not pass the test. And, we do not supply Western restaurant chains such as the McDonald's or Kentucky Fried Chicken. Nor do we export our meats." 32 In other words, he had no problem finding small supermarket buyers for his frozen chicken. As a report on livestock product quality states, profit drive was the main reason of poor meat and dairy quality on the market. ${ }^{33}$

The growth of China's livestock production and the industry's profit drive are closely linked to government's policy incentives. Despite economic liberalization, a lot cannot be accomplished without the endorsement of the Chinese government. In the following section, we shall highlight the major policy initiatives that have underlain the changes of China's animal farming industry.

\footnotetext{
${ }^{30}$ See Rodenburg, T. Bas and Paul Koene. (2007, p.205-214).

${ }^{31}$ China Animal Farming Information. (2008).

32 Interview with a slaughterhouse owner, Liaoning, China, June 22, 2005.

${ }^{33}$ China Animal Farming Information. (2008).
} 


\section{Policy Incentives for Livestock Production}

The growth, product structural change and industrialization of livestock production are attributable to policy incentives of China's proactive reforming state. Agriculture was the first target sector of the government's reform program. The reforming government attached great importance to rural development for its value in stabilizing the countryside and the entire nation. For that purpose, the reforming state adopted more than 3,000 policies related to rural development. In this section, we focus on the political rationale and the landmark policies that highlight state's facilitating role in the expansion of livestock production.

Food Security and Regime Stability

In 1978, when the Chinese Communist Party (CCP) started the reform program, it was facing the most serious legitimacy crisis. Mismanagement of the Chinese economy under Mao in the prereform era had created a totally deprived society. A policy-induced hunger claimed the lives of some 30 million peasants in the early 1960s. ${ }^{34}$ In the rest of the Mao era, the Chinese nation had never recovered from the trauma of the man-made disaster. The entire society was placed under the most brutal rule of the "tyranny of scarcity." Mass exodus to Hong Kong, the former Soviet Union, and even North Korea happened throughout the pre-reform era. ${ }^{35}$ Beggary was common. Villagers in the most devastated regions spent much of the slack seasons begging around the country. ${ }^{36}$ Compulsory state procurement of the rural products at prices set by the state destroyed peasants' production enthusiasm. State-rationing system through which urban residents received their meager rations made China's socialist state more repressive than NAZI Germany.

Yet, "hunger breeds discontent." Both within the CCP and without, dissenting voices against Mao's extremist collective policies began to appear soon after his death. In 1977, Deng Xiaoping asked if people would continue to tolerate the perennial food shortage any more. A reform program was therefore construed as the only way to restore the CCP's legitimacy. The reform

\footnotetext{
${ }^{34}$ Jones, Edwin F. (1962, p.1-11.). See also Becker, Jasper. (1997).

${ }^{35}$ See, for example, author unknown (2008). "The turmoil of 1962 mass exodus to Hong Kong: Declassified Shenzhen Documents."

${ }^{36}$ Zhang, Guangyou. (1995, p.154-161).
} 
program, a "Second Revolution" in the eyes of Western China watchers, was tasked to reestablish the CCP legitimacy through economic growth and an improvement of the people's lives. Deng Xiaoping warned Party veterans who opposed policy change that the CCP would face popular revolt if it could not deliver to the people a prosperous China, a promise it had made during the Civil War (1946-1949). ${ }^{37}$

Policy Change and Policy Incentives

In the pre-reform era (1949-1978), China pursued an extremist centrally-planned development. In the rural sector, peasants were members of the People's Commune, China's version of the Soviet state farms. They worked on the collective farmland and were reimbursed for their labor in kind or in money. What to grow, how much to hand in to the state, and how much to retain were all determined in accordance with state plans. Each peasant household was allotted small family plots for growing vegetables for their own consumption. Non-collective production activities beyond what was necessary for family consumption were discouraged. Peasant household production of non-grain sideline cash crops or of farm animals beyond family use were condemned. In rural China, land was in the hands of the state, so were all other means of production. Peasants were demoralized. Grain production, which had received much government attention, stagnated. The result was stagnation of the rural production and a severe food security crisis addressed above. ${ }^{38}$

Lifting Restrictions on Rural Production. The reform program was, therefore, aimed first to end the nation's food security crisis. The epoch-making $3^{\text {rd }}$ Plenum of the CCP's $11^{\text {th }}$ Party Congress, in launching the reform program, put forward the Draft Decision on the Several Questions on Accelerating Agricultural Development. This policy document called for arousing the peasants' production activism, allowing peasants to produce their chosen products on their private plots, encouraging and protecting household sideline production, and raising the government procurement prices of agricultural produce. The Plenum also accepted Deng Xiaoping's proposal that government should encourage some people, through their hard work, to get rich first. ${ }^{39}$ Most

\footnotetext{
${ }^{37}$ Chinese Communist Party Central Document Research Institute. (2004, p.380-381, p.450-451).

${ }^{38}$ For information on the widespread poverty in rural China as a result of the misguided "grain production first" rural policy under collective agriculture, see Zhang, Guangyou (1995, p.154-161).

${ }^{39}$ Chen, Minxian. (1989, p.472).
} 
relevant to this study, the Decision proposed to expand animal farming industry so that its share in agricultural output, about $17 \%$ of the total rural production, could be increased. ${ }^{40}$ It also called for increasing beef cattle, sheep and rabbit farming, improving livestock breeds, and a maximum use of the grassland. ${ }^{41}$ While still emphasizing the importance of grain production, it, however, put an end to the Maoist "grain production first" policy. Most significantly, the Decision decriminalized diversified agricultural production by individual peasants.

Based on the Party Decision, the Agriculture Ministry issued its first comprehensive Report on Accelerating the Development of Animal Husbandry Industry. The Report released in early 1979 emphasized the importance of increasing the share of grass eating livestock in farm animal total and the share of beef and mutton in consumption. It also called for implementing preferential policies to encourage peasants to raise more livestock. These incentives included provision of grain as feed to animal farming households and of extra land for feed grain production in regions with land abundance. The Report authorized the opening of rural livestock wholesale market. In addition, it confirmed state's decision to lift the ban on cattle slaughter so as to allow for trade in beef cattle. Soon after, the government raised the procurement price for some farm animal products. ${ }^{42}$ Peasant response to the Party-state's initiative was stunning. In 1979, livestock production grew by $20.27 \%$ over that in 1978 .

Disbanding Collective Farms. The liberalization policies at the 3rd Plenum had their limitations. Yes, it was no longer politically risky for the peasants to engage in non-collective and non-grain production on the private plots. Yet, the limited amounts of private plots each peasant household was assigned could produce little in excess of what was needed for household consumption. On average, every household could only raise one to two pigs utilizing vegetables grown in the private plots. Even raising one pig required the use of other feed made of assorted wild plants. Noticeably, the $3^{\text {rd }}$ Plenum failed to break down the opposition of the Maoists in the leadership who objected the abolition of the collective farms. ${ }^{43}$

\footnotetext{
${ }^{40}$ Department of Comprehensive Statistics of the State Bureau of Statistics. (2000, p.30).

${ }^{41}$ China Animal Husbandry Industry Yearbook Compilation Committee. (2000, p.161).

42 Ibid, p. 163-164.

${ }^{43}$, Zhang, Guangyou. (1995, p.121-231).
} 
A breakthrough was made only after fierce internal struggles between the reformers and their opponents. ${ }^{44}$ In September 1980, the CCP Central Committee issued Questions on Further Strengthening and Improving the Responsibility System in Rural Production also called "Document 75." This document officiated the dismantling of the People's Communes, China's state farms, and started land distribution to peasant households. In return to the allocated land, peasants were required under the contract responsibility system to repay in fixed amounts of the produce to the state. Surplus was to be marketed by the peasants in the rural markets or utilized for animal farming or other productive purposes to be determined by the peasants themselves. As a result of the new policy, peasant households saw farm land allocated under their control increase by ten folds or more depending on land availability. Such a sudden farmland increase made it possible for peasants to engage in non-grain productive activities in a scale that they could never even have dreamed about in the Mao era.

Land distribution provided the peasants with an important means of production to expand livestock farming. Yet, in the next four years, farm animal farming increased by $4.39 \%, 6.47 \%$, $3.89 \%$ and $8.78 \%$ in $1981,1982,1983$ and $1984 .{ }^{45}$ In contrast, grain output grew faster in 1982 and 1983 , for example, by $8.3 \%$ and $8.4 \%$. And when livestock production registered a bigger increase $(8.78 \%)$ in 1984 , increase of grain output dropped to $4.91 \%{ }^{46}$ Obviously, when the peasant households were allocated farmland, staple food production, i.e., grains, was the top priority to the peasants. By 1984, peasant fear of grain shortage was much alleviated. They started to expand non-grain production by utilizing the farmland under their control.

Utilizing Local Conditions. China's traditional animal farming region was located in the Western and Northwestern provinces. These included Inner Mongolia, Gansu, Ningxia, Qinghai, Xinjiang and Tibet. This is a vast area with 4.3 billion $m u$ ( 1 Chinese $m u$ equals to $1 / 15^{\text {th }}$ of a hectare) of grassland holding 80 million livestock in 1980, 14\% of the national total. The Agriculture Ministry Report on Accelerating the Development of Animal Husbandry Industry proposed that this traditional animal husbandry region should concentrate on livestock farming and return

\footnotetext{
44 Zhang Guangyou. (1995, p.147, 345).

${ }^{45}$ FAO Stat 2005.

${ }^{46}$ Department of Comprehensive Statistics of National Bureau of Statistics. (2000, p.33).
} 
cropland to grassland. ${ }^{47}$ Similarly, the Ministry recommended that grain-producing regions should utilize crop stalks, bran and other grain byproducts to develop livestock industry. Unlike the traditional animal farming region that was vast in area but sparse in population, the grainproducing provinces such as Sichuan and Shandong were densely populated. Surplus rural labor, according to the Report, could be diverted to animal farming. Furthermore, the hilly slopes and water systems in southern provinces should also be utilized for livestock and fish farming. Apparently, with the stabilization of grain supply by the mid-1980s, China began to see nonstaple food items such as meat and dairy products as important part of food security. Chinese officials believed that people who had meat on their dinner table were less discontented with their circumstances. ${ }^{48}$ Therefore, the Chinese government saw the need to boost the nation's nonstaple food production further to enrich the food baskets of the people.

To accelerate growth, the Party Central Committee and government called on local authorities to tap the unique advantages and endowments of the regions under their jurisdiction. In March 1981, the CCP Central Committee and State Council jointly endorsed and forwarded the State Agriculture Commission's Report on Actively Developing Diversified Production in the Rural Areas. This Report called for utilizing the more than 1 billion mu of grassy hills, 200 million mu of coastal wetland, and crops stalks and bran from 1.5 billion mu of cropland. Based on the belief that grain production was a precondition of livestock farming expansion, a Central Committee notice on Questions regarding the Current Rural Economic Policy offered the Party's directives. The Committee argued that animal farming production should resort to scientific use of animal feed. It agreed that the development of animal husbandry industry should not adversely impact grain production. ${ }^{49}$

While livestock farming was expanding, the authorities took notice of environmental devastation in the form of desertification caused by overgrazing in much of the northwestern regions. In 1988, the Agriculture Ministry issued Implementation Measures for Carrying out the State Council Decision on the Key Points of Current Economic Policies. For the first time, government called for a gradual scaling down of farming activities in the overgrazed areas so that grassland would not deteriorate to a point beyond repair. Importantly, the Measures recommended moving cattle and sheep farming from the prairies of the traditional animal

\footnotetext{
${ }^{47}$ China Animal Husbandry Industry Yearbook Compilation Committee. (2000, p.162).

${ }^{48}$ Interview with a Liaoning provincial agriculture official in charge of animal farming, June 21, 2005.

${ }^{49}$ China Animal Husbandry Industry Yearbook Compilation Committee. (2000, p.166).
} 
farming region to the grain-producing provinces. ${ }^{50}$ Similarly, the State Council in 1992 and the CCP Central Committee in 1998 issued their respective policy directives on further developing animal farming industry in the grain-producing regions. ${ }^{51}$ What followed was a steady increase in the number of grass-eating livestock and in the share of livestock production in the total output of the grain-producing provinces.

Removing Restrictions on Market. Removing obstacles that had suppressed the role of the "invisible hand" was a main policy objective of the reforming Chinese state. One of the earliest rural reform measures was the lifting of rigid state control of market and price. In the pre-reform era, peasant households could sell farm animals on the rural markets after they had fulfilled their obligations to the state. Yet, because of limited means and resources, individual peasant households could not raise more than what was needed to be handed over to the state. As a result, livestock markets were largely not oriented to the trading needs of the peasants. In the 1980 Agriculture Ministry Report on Accelerating Animal Husbandry Industry, the state allowed peasants to trade farm animals and determine the transaction price by themselves. In January 1984, the CCP Central Committee made a more far-reaching decision to the effect that state procurement of farm animals and animal products should reduce gradually with the increase of livestock output. To encourage production, the Central Committee recommended the further liberalization of the price of fresh and live farm animals in accordance to differences in seasons and regions. When state procurement was still in place, the Central Committee agreed, peasants should also be allowed to sell their products at prices determined by the market. These policy measures were specifically aimed at promoting livestock production. Through the decision, the Party expected quick results to end the nation's short supply of meat and dairy products. ${ }^{52}$

Noticeably, liberalization of state control of market and price continued in the mid-1980s. In a joint report on promoting goods circulation in rural areas, the State Economic Structural Reform Commission, Commerce Ministry, and Agriculture Ministry decided to further reduce the number of farm products under state compulsory procurement. Soon, the state procurement list was shortened from the original 21 to 12 items to still include such produce as rice, wheat,

\footnotetext{
${ }^{50}$ China Animal Husbandry Industry Yearbook Compilation Committee. (2000, p.172-173).

51 Ibid.

${ }^{52}$ China Animal Husbandry Industry Yearbook Compilation Committee. (2000, p.165-166).
} 
corn, groundnuts, rapeseeds, cottonseeds, and three kinds of cotton. Also, the produce that the state purchased through a routine yearly order was reduced from 18 to 9 . Still included in the state's special yearly purchase were live pigs, cattle hide, sheep wool, and others. No longer included in the special purchase were goat pelts, sheep pelts, beef, mutton, and eggs. Peasants could thereafter expand production of these products and market them for better price on the market.

Chinese peasants had been victims of the vicissitude of the government's rural policies in the pre-reform era. They feared that the new liberalizing policies could not last. In response to that fear, the joint report stated that only the State Council had the power to decide what produce to be procured and purchased. It stated that the government would not expand the existing procurement list. ${ }^{53}$ On the contrary, the list was soon to be removed. In January 1985, the Central Committee and the State Council jointly issued Ten Policy Measures on Rejuvenating Rural Economy. According to this policy statement, from 1985 on, the state would end once and for all the system of state procurement of agricultural products. This policy change suggested that peasants could directly sell all their livestock products on the markets. Livestock production in 1985 and 1986 was again most indicative of the enthusiastic response from the farming community. The average growth of livestock production in those two years reached $11.03 \%$.

Production of Scale and Industrialization. Modernization of livestock production has received consistent attention of the reforming state. Chinese reformist officials, state bureaucrats, and technocrats saw science and technology as a catalyst of productivity. In the early 1980s, the Chinese government encouraged peasant households to expand their production in one or several farm animal species so that they could transition to modern production of scale. It expected that households specialized in pig farming or geese farming, for example, could then modernize their operations by adopting the Western intensive farming model. This explains the rationale underlying the joint appeal of the CCP Central Committee and the State Council (1985) to the local authorities for the latter to encourage the formation of specialized farming households and farming villages. ${ }^{54}$ At about the same time, the Central Government decided that the country

\footnotetext{
${ }^{53}$ China Animal Husbandry Industry Yearbook Compilation Committee. (2000, p.167).

54 Ibid.
} 
was ready to build intensive animal farming production bases. To the Chinese authorities and the farming industry, the Western intensive farming model was more efficient and productive.

In the mid-1980s, a large number of intensive farms were built mostly in the suburbs of China's major urban centers and provincial capitals. These new concentrated farming facilities served several purposes. First, they were the production sites that could quickly supply the urban markets. Second, they were the fattening facilities to supply the local slaughterhouses. Third, they bred and introduced from abroad fine foreign breeds for growing farms. Fourth, they were sites for showcasing Western intensive farming techniques and for training purposes. Finally, these intensive farms served as the "storage" or supplier of the national "pork reserve," a mechanism unheard of in any other country. Understandably, fluctuations of meat supply in China, like oil supply in the industrialized nations, could affect consumer confidence and trigger social instability.

In the 1990s, the Chinese government was more explicit in supporting farming operations of scale. It moved to provide policy incentives for building animal feed plants, modernizing animal drug plants, and supporting the import of foreign breeding stock. Local governments were even more aggressive in supporting livestock and related businesses through tax breaks, preferential land rental fees, and little or no requirements on labor and environmental protection. It was also during this period that the Chinese government began to encourage sales of live farm animals and products overseas. International cooperation in animal disease control and prevention also received government attention. Paradoxically and not completely surprisingly, the outbreak of SARS and the bird's flu, epidemics caused partially by concentrated farming systems, hardened the Chinese authorities' determination to push for the industrialization of the production. The Chinese authorities are yet to realize that farm animals in concentrated units are more vulnerable to mass epidemic outbreaks. To the Chinese agricultural bureaucrats and the farming industry, productivity is above any other considerations.

The Chinese government's rural policies reviewed in this section succeeded in sending important messages to the peasants. First, the nation's food security could not depend on grain production only. While agriculture is "an industry that is vital to social stability," in the words of the CCP's former General Secretary Jiang Zemin, grain production and diversified non-grain production had to receive equal attention. Importantly, diversified production was to be encouraged rather than penalized. Second, relaxation of state control over price and market, 
lifting of state ban on cattle slaughter, provision of feed grain and bonus farmland to livestock farming households, and de-collectivization were all indispensable moves to reassure the farmers that the government meant what it pronounced. Quite expectedly, these policies helped unleash a new wave of entrepreneurial spirits among the peasants who were willing to invest in long-term growth of animal farming. Specialized livestock farming households emerged in great numbers. By the mid-1980s, livestock production had increased to a level prompting the Chinese government to remove meat and dairy products from the state rationing system imposed since the mid-1950s. While China had made impressive progress in food security by the early of the 1990s, it however began to face a challenge of no less danger to social stability.

\section{Intensive Farming and Consequences}

The preceding section does not pretend to cover all the policies made by China's reforming state for promoting livestock production. The introduced policies are, however, some of the landmark policy changes with far-reaching significance. Lifting price control, for example, was for encouraging peasants to farm more animals. Opening markets was for the peasants to benefit from increased production. Encouraging production intensification was for maximizing the gains from adopting Western farming model and practices. As we have introduced earlier in this paper, China's livestock production has experienced a breathtaking growth and product structural changes. In 1990, China surpassed the US as the world's biggest meat producer. This is one of the many areas that China succeeded in its "catch up" efforts during the reform era. Yet, like in the industrialized nations, industrial animal farming and Western farming practices create enormous environmental and human health problems. And the severity of the problems is still unfolding.

Animal Cruelty, Disease Control and Environment

In European Union nations, Western farming practices are criticized for their adverse impact on farm animal welfare. This criticism has been unknown to most if not all Chinese farmers. High stocking density, a common site on Chinese intensive farms, makes disease spread like prairie fire. According to a study, 42 of the 48 farms hardest hit by H5N1, a variant of avian influenza, 
in 2005 were concentrated farming units. ${ }^{55}$ To prevent or control disease outbreaks, farms resort to drugs. Little wonder that farm animals in China's intensive farms are kept alive through drug use until, in most cases, the last day on the farm. What is equally shocking to Chinese consumers is the use of wide varieties of additives in commercial feed. These substances promote growth at the expense of the farm animals and human health.

As our field study confirmed, Western farming practices are hugely popular in China because of their value in promoting growth and productivity. Sow stalls are universally used in breeding farms. This equipment severely limits sows' freedom of movement and their ability to perform many natural behaviors. Confined sows are not only physically exhausted, but also mentally distressed. Being relentlessly milked by their piglets who have nothing else to do in the barren pens, sows' immune system could drop thus creating the need for drug intervention. Similarly, mutilation causes long-term pain to the piglets making them susceptible to viral attack. Drug use is again necessary on the farms. Living in barren pens, piglets resort to fighting to overcome boredom. Injuries from fighting are an apparent reason for drug use. And, drugs are also used before loading the livestock for the slaughterhouse to ensure that they do not die on the road.

Farm animal waste contaminates water and soil in the West. Its damage to environment in China is even more serious. Untreated waste discharged from these farms constitutes a huge environmental challenge. ${ }^{56}$ According to one study, livestock industry was responsible for $37 \%$ of the waste discharge into China's water systems. Its $\mathrm{CO} 2$ contribution exceeds the world average contributing level of $18 \%$ to the global green house effect. Parts of the suburbs of most provincial capitals are declared uninhabitable for human residents because of a high level of methane discharge and other gaseous pollution. ${ }^{57}$ Beijing and Shanghai have been moving animal farms out to the nearby provinces or remote suburbs ending air pollution problems in the vicinity of the metropolises but polluting the rural areas. ${ }^{58}$

\section{Food Safety}

Daily mortality on China's factory farms, particularly broiler, laying hen, and duck farms, is no small number. Relevant regulations require deep burial or other safe treatment of these dead

${ }^{55}$ CAAC. (2005a).

${ }^{56}$ Chong, A. (2007).

${ }^{57}$ Interview with a provincial agriculture bureau official in charge of animal farming, June 14, 2005.

${ }^{58}$ CAAC. (2005b). 
animals. Yet, there have long been reports in China about discarded broilers, for example, collected and made into roast chickens. ${ }^{59}$ Our field study confirmed the widespread violation by farm owners, livestock trader,s and food processors regarding farm mortality disposal. Out of the eight layer farms, three sold the dead chicken to their own employees who may in turn resell them to restaurants or other food dealers. And, five of the seven pig farms disposed of dead pigs to vendors who make a living collecting and processing dead farm animals.

It is, therefore, safe to say that most of the daily farm mortality in China finds its way to the food market. ${ }^{60}$ According to a Chinese study, a significant portion of the meat products on the market could hardly stand a standard drug residue test. ${ }^{61}$ Relevant regulations require the farmers to stop using drugs to their livestock days before slaughter depending on the drug used. Yet, our interviewees confirmed that most farms do not go by that rule. Local governments are not motivated to enforce the regulations for fear of slowing down livestock production. As a result, meat and dairy products with high drug residue and other substances are a constant concern to the Chinese consumers. One study conducted in South China's Guangzhou found that, out of the 200 samples of pork liver sold on the market, $68 \%$ were found to have pathological changes such as cancerous cells in the very early stage of development caused by over-dose of drugs in the pigs' entire life cycle. ${ }^{62}$

As we have already mentioned, Chinese farms have been found using banned chemicals such as Ractopamine, Salbutamol, Terbu-taline, and Clenbuterol, and other synthetic growth promoter, to produce lean meat. These chemical compounds were found in 5\% of the pork sold in Shanghai in 2004. Pork contaminated with these chemicals was responsible for the hospitalization of some 300 people in the city in $2006 .{ }^{63}$ The tainted baby formula is the latest of food safety incident involving the farm animal farming industry. What explains the stubbornness of the problem? Profit drive of the businesses involved and government failure to enforce food safety regulations have been identified by some scholars as the direct causes. ${ }^{64}$

Admittedly, Western farming model and technology are efficient in achieving quick results in the shorted possible time. And, they are more productive compared with traditional farming

\footnotetext{
${ }^{59}$ Shi, Wenxian. (2001); See also, Wu, Hui and Wei Tao. (2004).

${ }^{60}$ CCTV. (2004).

${ }^{61}$ LYXMJ. (2008).

${ }^{62}$ HHHTAGRI. (2007).

${ }^{63} \mathrm{Yu}$, Lihong and Wanf Wei. (2006).

${ }^{64}$ SDXM. (2008).
} 
methods. After adopting Western farming model and practices, livestock production has become the fastest sector in Chinese agriculture. In 1990, China produced 30.42 million tons of meat, doubling that of 1980. Fifteen years later, China's meat output reached a record high of 78 million tons representing $29.26 \%$ of the world's total. Per capita meat consumption in China hit 63 kilograms. ${ }^{65}$ Although peasant household-based production continues to dominate pig farming in sheer numbers, for example, factory farms contributed a higher and disproportionate share $(27 \%$ in 2005$)$ to the total pork output. Shortage of meat supply is history.

\section{Dietary Change and Public Health}

In the reform era, China's cereal-based diet has undergone noticeable changes. Ample supply of farm animal products made it possible for Western fast food chains such as the McDonald's to build outlets in massive scale and at an unprecedented speed. Intake of larger amounts of animal proteins is believed to be a major cause of the sudden rise of chronic illnesses. Today, an average Chinese youth is taller than his or her parent generation. According to one study, $22 \%$ of the adults in China are over-weight while $7.1 \%$ of them are obese. In major metropolises, as high as $30 \%$ and $12.3 \%$ of the adults are over-weight and obese. Compared with the data collected in 1992, by 2006, adults who were overweight and obese had gone up by 39\% and 97\% respectively. Nationally, $8.1 \%$ of schoolchildren are obese. Ample supply of meat and dairy products in recent years has encouraged a compensatory meat consumption attitude among those who lived through the hard days of the pre-reform era. The dominance of meat, dairy, and fat intake in daily diet is believed to be a contributing factor of weight increase in China. Surprisingly, weight gains are reportedly quite even among both the urban and rural adults. ${ }^{66}$

Weight gain is only the symptom of a changing dietary habit in China. Like in many other developed countries, cases of infectious diseases have been steadily going down in China. In contrast, chronic illnesses or "diseases of affluence" have been rising quickly. In 2002, there were reportedly 134 million high blood pressure patients, an increase of 50\% over that in $1980 .^{67}$ Worse still, increased food supply has been accompanied by a corresponding rise in the number

\footnotetext{
${ }^{65}$ CAAC. (2007).

${ }^{66}$ Wang, Rongde (2007).

${ }^{67}$ CHINAPOP. (2004).
} 
of cancer patients in China. According to a World Health Organization estimate, China has become the second biggest country in the number of yearly new cases of cancer patients. ${ }^{68} \mathrm{An}$ authoritative survey data also revealed that three million Chinese died of cancers in 2006, 100\% increase in cancer-related deaths over that in 1986. Deaths from cancers most directly linked to over consumption of meat ranked fourth in number. ${ }^{69}$ Each and every modern farming practice adopted on the Chinese farms creates opportunity for drug use to prevent disease outbreaks. People today may not suffer from undernourishment as they were in the pre-reform era; yet they are not necessarily healthier. When they are hospitalized, their body may be resistant to treatment drugs due to years of overdose from drug tainted farm animal products.

Like other developmental states in East Asia, China has come to a juncture in development. How can it sustain growth while starting to care about other important concerns such as environmental protection and food safety? In essence, can China afford to continue the option of "pollute first and clean up later"? Similarly, is China's animal farming sustainable if it continues to expand at the expense of animal welfare, environment, and human health?

\section{Conclusions}

China watchers worldwide have been amazed at the role of government policy in facilitating stunning changes in China. ${ }^{70}$ This paper has explored the relations between the new policies of the reforming Chinese state and growth of livestock production. In an effort to promote growth, the Chinese reforming state has acted like other developmental states in the region. It has used state policies to achieve several important objectives. First, government policies were enacted to change the attitude of the peasants' towards production. By de-criminalizing non-state and nongrain production, the Chinese government set forth a production enthusiasm never seen in the pre-reform era. Second, government policies were made to effect change in the distribution of livestock production in the country. By encouraging peasants in the grain-producing areas to

\footnotetext{
${ }^{68}$ Medicine and Economics News. (2008).

${ }^{69}$ Harbin Daily reporter. (2007).

${ }^{70}$. According to a New China News Network report, an American reporter who was stationed in China in the early 1980s expressed her shock at the earth-shaking changes that have taken place in the country. She reportedly was most amazed at the role of government policy in awakening the long-suppressed entrepreneurial spirits among the Chinese. See CREADER. (2008).
} 
engage in expanded farm animal farming, the Chinese government succeeded in moving livestock farming east-ward and to areas with abundant surplus labor and abundant crop byproducts. In the meantime, the state succeeded in causing a change in the product structure of China's livestock production. The dominance of pig farming has been eroded. Cattle and sheep farming has been on the rise.

Third, the most fundamental change Chinese government policies have been pushing for is transformation of production model. Peasant backyard farms still dominate animal farming in absolute numbers. Yet, intensive farms are growing. Industrialization has been identified as the future direction of the nation's livestock production. The role of government policy in facilitating desired changes in China has been widely recognized. The power of the policies lies, however, in the fact that they have catered to the growth desire of the producers. Yet, it is this obsession with growth that partially explains the lack of attention on issues ranging from environmental degradation to food safety. Therefore, we believe that China's reforming state is as much a cause of the development ailments as part of a solution. Can China's developmental state that sees growth as the primary objective solve the nation's sustainable development challenge? Or, has mainland China come to a historical juncture to move beyond the politics of a developmental state as Taiwan and South Korea did in the late 1980s?

\section{Acknowledgements}

I wish to thank the four anonymous reviewers for their excellent and insightful comments and suggestions. I would also thank the Humane Society International and the British Compassion in World Farming for their generous support of an earlier research on China's animal farming industry from which this paper draws much valuable information. 